www.jmscr.igmpublication.org

Impact Factor 5.84

Index Copernicus Value: 83.27

ISSN (e)-2347-176x ISSN (p) 2455-0450

crossref DOI: _https://dx.doi.org/10.18535/jmscr/v5i8.113

Journal Of Medical Science And Clinical Research

\title{
Premalignant mucosal lesions in gallbladder is a rarity in south Indian patients undergoing cholecystectomy - A single centre experience
}

\author{
Authors \\ Mayank Jain ${ }^{1}$, Vaithiswaran $\mathrm{V}^{2}$, Sruthi Shankar ${ }^{1}$, Mukul Vij ${ }^{3}$, Tom Michael, \\ Jayanthi Venkataraman ${ }^{1}$ \\ ${ }^{1}$ Department of Gastroenterology, ${ }^{2}$ Gastrointestinal Surgery and ${ }^{3}$ Pathology \\ Gleneagles Global Health City, Chennai-100 \\ Corresponding Author \\ Mayank Jain \\ Gleneagles Global Health City Chennai-100 \\ Email: mayank4670@ rediffmail.com
}

\begin{abstract}
Aim: To determine the prevalence of metaplasia and dysplasia among south Indian patients undergoing cholecystectomy.

Materials and Methods: Patients undergoing laparoscopic/ open cholecystectomy from January 2015 to December 2016 were included. Retrospective data on age, sex, residence and presence of common bile duct stones was collected. Peri operative information included colour of gallstones and histopathology of the gallbladder.

Results: 235 gallbladder specimens (115 males) with median age of 49.3 years (17-83 years) were studied. Chronic cholecystitis was the commonest pathological finding followed by acute on chronic cholecystitis, acute cholecystitis and acute necrotising cholecystitis respectively. Six specimens (2.5\%) showed an antral metaplasia and one each (0.4\%) had focal micropapillary changes and low grade dysplasia.

Conclusion: Gallstone related cholecystitis in south India is often chronic and affects men and women equally. Chronic cholecystitis though the commonest pathological type was not associated with metaplasia or gallbladder cancer.

Keywords: gall bladder, premaliganat, India, mucosa.
\end{abstract}

\section{Introduction}

The incidence of gall bladder cancer (GBC) varies across the world ${ }^{1-6}$. The close link between gallstones and gall bladder cancer is frequently reported from the Gangetic plain in north India. GBC is relatively rare in south India ${ }^{6,7}$. Based on the Adyar Cancer Registry from Chennai, pooled information from 19 hospitals within the city (both public and corporate hospitals), the prevalence figure of GBC was $0.52 \%$ amongst men and $0.66 \%$ amongst women. Majority of patients were in the 5 th to 7 th decade $^{8}$.

The present study was undertaken to determine the prevalence of premalignant mucosal changes in cholecystectomy specimens and to correlate these with type of gallstones. 


\section{Materials and Methods}

Retrospective study was done among Indian patients who underwent laparoscopic/ open cholecystectomy from January 2015 to December 2016 at Gleneagles Global Health City, Chennai. Baseline information included age, gender, state of origin and indication for cholecystectomy (acute, recurrent right upper quadrant pain, asymptomatic and incidental) in patients with ultrasound proven GSD. Details of colour, size and texture of GS were noted. By visual inspection, black amorphous GS and size less than $0.5 \mathrm{~cm}$ were labelled as pigment GS, those faceted with green, brown, yellow or a combination of any of these irrespective of size was labelled as mixed GS and those white and faceted as cholesterol GS ${ }^{9}$.

The histology details were classified as

Acute cholecystitis when there was mucosal ulceration, congestion in lamina propria and polymorphonuclear / mixed cellular infiltration.

Chronic cholecystitis- mucosal thickening, chronic inflammatory infiltrate in lamina propria, thickened muscular layer, presence of numerous Rokitansky - Aschoff sinuses (RA sinus)

Acute on chronic cholecystitis- mucosal ulceration, mixed cellular infiltration on a background of thickened muscular layer and RA sinuses

\section{Acute necrotising / gangrenous / empyema} cholecystitis - diffuse mucosal ulceration/ denudation, transmural inflammation, microabscesses, congestion and neutrophilic infiltration

Xanthogranulomatous cholecystitis - mucosal ulceration, inflammatory infiltrate consisting of histiocytes, plasma cells, lymphocytes and foreign body giant cells.

Cholesterolosis- features of chronic cholecystitis with cholesterolosis.

The surface epithelium description for cholesterolosis, hyperplasia, metaplasia, dysplasia and malignant changes was specifically noted.
From the operative notes, data regarding colour, character and size of stones and histopathology study details were obtained and categorised accordingly. The collected data was tabulated in Microsoft Excel sheet and analysed using appropriate statistical tests.

\section{Results}

A total of 235 patients (115 males) underwent cholecystectomy during the study period. The median age was 49.34 years (range 17-83 years). $35.8 \%$ of patients were $>60$ years of age; $78(33.2 \%)$ were below 40 years of age and $31 \%$ (73) were 40-60 years old. 223 patients(95\%) belonged to the southern states (Tamil Nadu, Andhra Pradesh, Puducherry) while 12 patients were from the Gangetic Belt. Twelve patients with choldedocholithias had a preoperative ERCP. All patients except 5, had symptomatic gallstone disease. One female patient from Tamil Nadu had a preoperative diagnosis of carcinoma gall bladder and underwent radical cholecystectomy. This patient had mixed gallstones. GS information was available in 113 patients. Majority of the stones were pigment stones (87, 77\%), followed by mixed stones $(23,20.4 \%)$ and cholesterol stones $(3,2.6 \%)$. The average size of pigment, mixed and cholesterol GS were $0.4 \mathrm{cms}, 0.6 \mathrm{~cm}$ and $1.2 \mathrm{~cm}$ respectively.

The histopathological changes noted in the gall bladder specimens are shown in Figure 1. Chronic cholecystitis was the most common histopathological finding followed by acute on chronic cholecystitis, acute cholecystitis and acute necrotising cholecystitis respectively. Antral metaplasia was noted in 6 specimens $(2.5 \%)$; one patient each had focal micropapillary changes and low grade dysplasia $(0.4 \%)$. 
Table 1- Comparison of findings of the studies from Northern India with the present study

\begin{tabular}{|c|c|c|c|c|c|c|}
\hline STUDY & $\begin{array}{l}\text { NO. } \\
\text { OF } \\
\text { CASES }\end{array}$ & $\begin{array}{l}\text { MALE: } \\
\text { FEMAL } \\
\text { E }\end{array}$ & $\begin{array}{ll}\text { COMMON } & \text { HISTOPATHOLOGY } \\
\text { FINDINGS } & \end{array}$ & $\begin{array}{l}\text { METAP } \\
\text { LASIA }\end{array}$ & $\begin{array}{l}\text { DYSPL } \\
\text { ASIA }\end{array}$ & $\begin{array}{l}\text { GB } \\
\text { Cancer }\end{array}$ \\
\hline Mondal B et al [9] & 786 & $151: 635$ & $\begin{array}{l}\text { chronic cholecystitis }(79.8 \%) \\
\text { acute-on-chronic cholecystitis }(6.1 \%) \\
\text { cholesterolosis }(2.9 \%) \\
\text { xanthogranulomatous cholecystitis } \\
(1.7 \%)\end{array}$ & $4.7 \%$ & $2.2 \%$ & $0.6 \%$ \\
\hline Sangwan MK et al[10 & 530 & $1: 6.07$ & $\begin{array}{l}\text { Chronic cholecystitis69.8\% } \\
\text { Acute cholecystitis11.9\% } \\
\text { Cholesterolosis 9.43\% } \\
\text { Xanthogranulomatous cholecystitis } \\
2.64 \%\end{array}$ & $6 \%$ & & $1.9 \%$ \\
\hline $\begin{array}{l}\text { Devi S, Kalita D. J. [11] } \\
03 \text {. }\end{array}$ & 682 & $1: 3$ & & $4.5 \%$ & $2.34 \%$ & $0.88 \%$ \\
\hline Dattal DS et al.[12] & 1371 & $1: 8.3$ & Chronic cholecystitis 94\% & & $1.5 \%$ & $0.5 \%$ \\
\hline PRESENT STUDY & 235 & $1: 1.04$ & $\begin{array}{l}\text { Chronic cholecystitis } 66 \% \\
\text { Acute on chronic cholecystitis } 15.7 \% \\
\text { Acute cholecystitis } 7.7 \% \\
\text { Acute gangrenous cholecystitis } 6.8 \% \\
\text { Xanthogranulomatous cholecystitis } 0.9 \% \\
\text { Cholesterolosis } 1.3 \%\end{array}$ & $2.5 \%$ & $0.4 \%$ & $0 \%$ \\
\hline
\end{tabular}

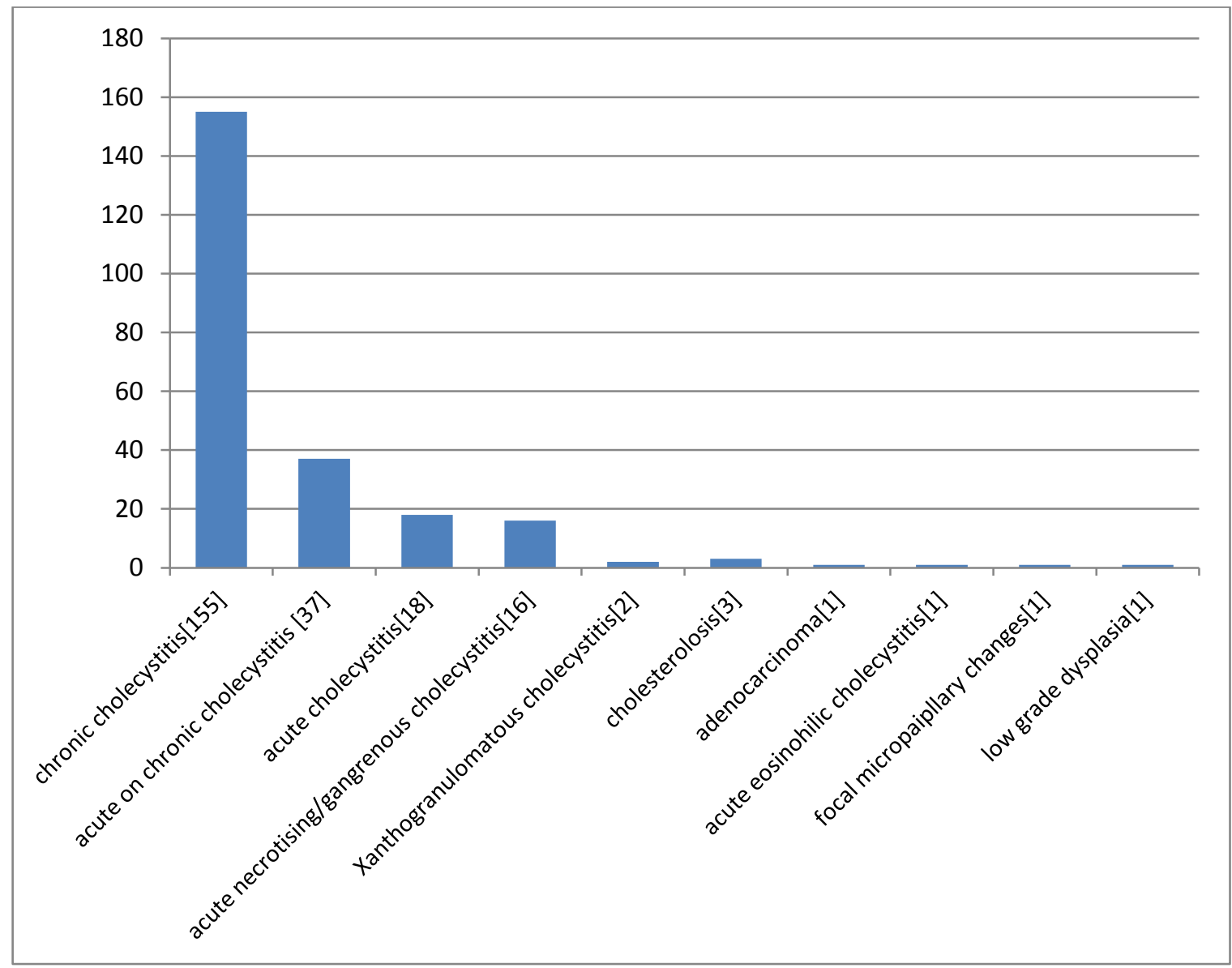

Figure1- histopathological findings in cholecystectomy specimens

\section{Discussion}

Cholecystectomy is a common abdominal surgery for gall stone disease. The histology of the surgical specimen is very helpful and gives additional information regarding metaplasia and dysplasial ${ }^{10}$. There are several studies from North India that have addressed prevalence of premalignant changes and include metaplasia (4.5- 
$6 \%$ ) and dysplasia (1.5-2.34\%) (Table 1). Mathur et al ${ }^{10}$ correlated the mucosal changes with size and weight of the stone. Their study concluded that weight, volume and size of the stone cause changes in GB wall mucosa that ranges from cholecystitis, hyperplasia, metaplasia, dysplasia to carcinoma.

The present study cohort was predominantly from the southern states. Compared to the above mentioned studies, the sex distribution in our series was distinct. While the studies from North India report a female predominance of cholecystectomy, we found equal number of men and women patients undergoing cholecystectomy. Cholecystectomy was common above 40 years of age, more so > 60 years. Although chronic cholecystitis was the commonest histopathological abnormality detected, the incidence of xanthogranulomatous cholecystitis $(2,0.9 \%)$ and cholesterolosis $(3,1.3 \%)$ was much lower than reported from North. Metaplasia was noted in $2.55 \%$ and dysplasia in $0.4 \%$ of cases; these figures are significantly lower than in Northern states. These findings correlate with high proportion of pigment or mixed GS in our patients. The mean size of the GS was less than a centimetre. We have recently reported that bile in patients with pigment GS from south India are less lithogenic compared to those with cholesterol GS ${ }^{15}$. Incidental Gallbladder Carcinoma (IGBC) is the carcinoma of the gallbladder which is suspected for the first time during cholecystectomy or which is found on the histological examination of the gallbladder. No incidental GBC was detected in the present study. The present study highlights that over the years, there has been no significant change in the variety of stones ${ }^{16}$ and incidence of GBC in South India. Gallstones in south India are predominantly pigment with low or no risk to GB cancer. Studies looking into genetic factors that protects south Indians to GB cancer needs to be pursued in the future. In conclusion, GS disease affects men and women with equal frequency in the South. Cholecystectomy is more frequent above 40 years of age and predominantly above 60 years. Chronic cholecystitis is the commonest histopathological abnormality. Xantogranulomatous cholecystitis and cholesterolosis is rare. Gall bladder metaplasia, dysplasia and incidental GBC are infrequent in South India

\section{Conflict of interest- none \\ Funding- none}

\section{References}

1. Randi G, Franceschi S, Vecchi CL. Gallbladder cancer worldwide: geographical distribution and risk factors. Int J Cancer. 2006;118:15911602. doi: 10.1002/ijc.21683.

2. Diehl AK. Epidemiology of gall bladder cancer: A synthesis of recent data. J Natl Cancer Inst. 1980;65:1209-1214

3. Tominaga S, Kuroishi T. Biliary tract cancer. Cancer Surv. 1994;19-20:125137.

4. Fraumeni JF, Jr, Devesa SS, McLaughlin JK, Standford JL. Biliary tract cancer. In: Schottenfeld D, Fraumeni JF, editors. Cancer epidemiology and prevention. New York: Oxford University Press; 1996. pp. 795-805.

5. Zatonski WA, Smans M, Tyczynski J, Boyle P (1996) Atlas of cancer mortality in Central Europe. Lyon: IARC 56-9

6. Kapoor VK, McMichael AJ. Gallbladder cancer: An 'Indian' disease. The Nat Med Jour India. 2003;16:209-213.

7. Zatonski WA, Lowenfelds AB, Boyle P, et al. Epidemiologic aspects of gall bladder cancer: A case-control studyof the SEARCH programme of the International Agency for Research on Cancer. J Natl Cancer Inst. 1997;89:1132-1138. doi: 10.1093/jnci/89.15.1132.

8. Shanta V, Vendhan Gajalakshmi V, Swaminathan R, Rama R. Population based cancer registry, Chennai. Cancer Institute (WIA), Adyar, Chennai. Individual Registry Data: 1990-1996; 173-94 
9. Gokulakrishnan S, Murugesan R, Mathew S, Prasanthi R, Ashok AC, Ramesh H, Sivakumar G, Surendran R, Jayanthi V. Predicting the composition of gallstones by infrared spectroscopy. Tropical Gastroenterology 2001; 22:87-89

10. Mathur SK, Duhan A, Singh $S$ et al. Correlation of gall stone characteristics with mucosal changes in gallbladder. Tropical Gastroenterology 2012;33(1):39-44

11. Mondal B, Maulik D, Biswas BK, Sarkar GN, Ghosh D. Histopathological spectrum of gallstone disease from cholecystectomy specimen in rural areas of West Bengal, India- an approach of association between gallstone disease and gallbladder carcinoma. Int $\mathbf{J}$ Community Med Public Health 2016;3: 3229-35

12. Sangwan MK, Sangwan V, Garg MK, Singla D, Malik P, Duhan A. Incidental carcinoma of gallbladder in north India: is routine histopathology of all cholecystectomy specimens justified? Int Surg J 2015;2: 465-7

13. Devi S, Kalita D. J. Metaplasia-dysplasiacarcinoma sequence in cases of cholelithiasis: a histopathological study. Int J Med Res Rev 2016;4 (7):10921096.doi: 10.17511/ijmrr.2016.i07.03

14. Dattal DS, Kaushik R, Gulati A, Sharma VK. Morphological spectrum of gall bladder lesions and their correlation with cholelithiasis. Int $J$ Res Med Sci 2017;5:840-6

15. Jayanthi V, Sarikha S, Varghese J et al. Composition of Gallbladder Bile in Healthy Individuals and Patients With Gallstone Disease From North and South India. Indian J Gastroenterol 2016; 35, 347-353
16. Jayanthi V, Palanivelu C, Prasanthi R, Mathew S, Srinivasan V. Composition of gallstones in Coimbatore District of Tamil Nadu state. Indian $\mathbf{J}$ Gastroenterol. 1998;17:134-5. 